\title{
In memory of William D. Ehmann, 1931-2013
}

\author{
Steven W. Yates
}

Received: 7 May 2014/Published online: 10 June 2014

(c) Akadémiai Kiadó, Budapest, Hungary 2014

William ("Bill") Donald Ehmann was born on February 7, 1931 in Madison, Wisconsin, and died on December 17, 2013 in Lexington, Kentucky. Bill received B. S. (1952) and M. S. (1954) degrees in Chemistry from the University of Wisconsin, and married Nancy Gallagher on July 16, 1955 in Milwaukee, Wisconsin. In 1957, he received a Ph.D. in Radiochemistry from (now) Carnegie Mellon University in Pittsburgh, working with Prof. Truman P. Kohman. After 2 years as a postdoctoral fellow with John R. Huizenga at Argonne National Laboratory, where Bill began using neutron activation analysis, he accepted a faculty position at the University of Kentucky (UK) in Lexington, Kentucky and quickly rose through the ranks to become a Professor of Chemistry.

Named a Fulbright Research Scholar in 1964, Bill traveled to Australia for a year where he completed ground-breaking research on meteorites. In the 1970s, he was chosen by NASA to be included in the first group of scientists to analyze moon samples from the Apollo missions. In later years, Bill's research focused on the relationship between trace elements and Alzheimer's disease. He presented his research at more than a hundred conferences around the world and published over 200 papers in refereed journals. With Diane Vance, Bill wrote the wellreceived textbook, Radiochemistry and Nuclear Methods of Analysis, which arose from the lecture notes for his beloved radiochemistry course. A more comprehensive review of Bill's contributions as a radioanalytical chemist and radiochemistry educator is given in the introduction to the

S. W. Yates $(\square)$

Departments of Chemistry and Physics and Astronomy,

University of Kentucky, 307 Chemistry-Physics Building, Lexington, KY 40506-0055, USA

e-mail: yates@uky.edu issue of the Journal of Radioanalytical and Nuclear Chemistry (Vol. 219, No. 2 (1997) 153) published in his honor.

During his 35 years at the University of Kentucky, Bill received numerous honors. The UK College of Arts and Sciences elected him as the Distinguished Professor in 1968 and inducted him into its Hall of Fame in 2010. In 1987, he received the William B. Sturgill Award for his contributions to graduate education at UK. Bill also believed in service to the University and his four-year term (1972-1976) as Chair of the UK Department of Chemistry was followed by an appointment as Associate Dean for Research in the Graduate School. He received the Kentucky Academy of Science Distinguished Scientist Award in 1982 and the American Chemical Society's Award for Nuclear Chemistry (now the Seaborg Award) in 1996. In the same year, the American Nuclear Society created the W. D. Ehmann Award in his name, for which he was the first recipient.

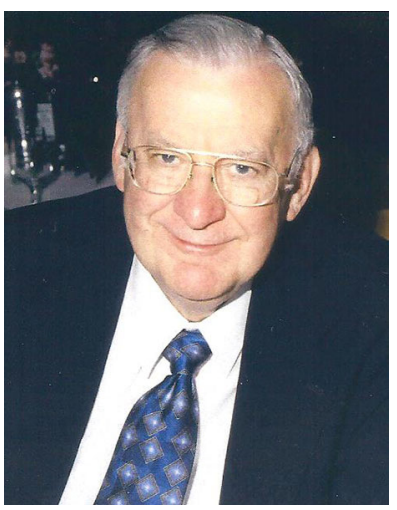

Beyond his remarkable career as a scientist, which is recounted in his personal narrative, "From a rock to a hard 
place: Journeys of a radiochemist through inner and outer space" (Journal of Radioanalytical and Nuclear Chemistry, 219 (1997) 157), Bill loved the outdoors and was an avid hiker, fisherman, and rock-hound. He and Nancy (now deceased) traveled the world, visiting dozens of countries. The family's fondest memories are of the annual fishing and camping trips to the remote lake country of northern Wisconsin, where his ancestors first settled from Germany. Bill is survived by sons Bill (wife Susan), John, and Jim (wife Muthoni), daughter Kathleen (husband Steve) and grandchildren George and Alex.

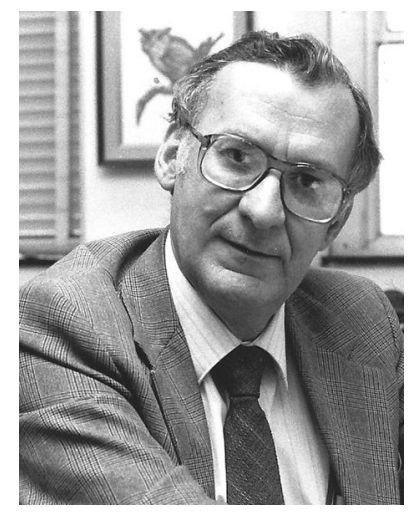

